\title{
Eletro-Metalúrgica Brasileira de Ribeirão Preto
}

\author{
Pedro Wagner Gonçalves \\ Natalina Aparecida Laguna Sicca \\ Marcelo Luis de Brino
}

\section{EMENTA - WORKSHOP}

A oficina explora materiais didáticos e sua fundamentação apoiada na teoria de sistemas, escalas de tempo e narrativas interpretativas do passado, bem como na importância do conhecimento da cidade e do local. A História da Ciência e da Técnica contribui para recuperar e reconstruir o contexto das alternativas e opções conflitantes diante das quais se implantavam as primeiras siderúrgicas do Estado de São Paulo. Os pioneiros dessa indústria precisaram prospectar e descobrir jazidas de ferro e calcário, bem como desenvolver o uso do carvão. As tentativas de industrialização na Primeira República exemplificam contradições dos projetos das elites brasileiras ao buscar reproduzir o capital gerado pela economia agroexportadora. A Eletro-Metalurgica Brasileira de Ribeirão Preto (1921-1931) foi um dos poucos empreendimentos que empregaram alto-forno elétrico para produzir aço. Pesquisa colaborativa promovida por professores do ensino público (de Biologia, Geografia, História, Matemática e Química) busca valorizar parte esquecida dos eventos ocorridos na cidade. Para promover a integração curricular promove o levantamento das ruinas da siderúrgica, das estações e ramais ferroviários empregados pela empresa, bem como a mineração de ferro e calcário situadas em Jacui (Minas Gerais). Dessa forma, produz materiais curriculares que são desenvolvidos para o ensino médio e podem ser usados por outros professores. Entre os objetivos desta proposta encontra-se a valorização dos bens culturais e naturais da cidade que usualmente se perdem na malha urbana. Ao difundir tais materiais, conduz ao reconhecimento das possibilidades de inter-relações e construção curricular pondo no centro do eixo de conteúdo a História da Ciência e da Técnica e, ao mesmo tempo, cruzando dados coletados de História Regional, Biologia, Geografia, Matemática e Química. O tratamento dos assuntos persegue eixos que partem da escala do tempo histórica e avança para 0 tempo da natureza, mostram vínculos e articulações de diferentes campos do conhecimento por meio da cadeia industrial, sua dependência de matérias primas naturais e a indissociabilidade entre a história geológica e os locais de concentração de minérios (ferro e calcário). A oficina opera com documentos originais da Companhia de Força e Luz de Ribeirão Preto, com documentos da história da eletrificação, 
abastecimento de água e redes de esgoto de cidades do interior atendidas por essa empresa. Adicionalmente recorre a audiovisuais e amostras coletadas nos locais que foram palcos dos eventos. 